\author{
MONIKA LEŚKIEWICZ \\ Zakład Neuroendokrynologii Doświadczalnej \\ Instytut Farmakologii im. Jerzego Maja PAN \\ Smętna 12, 31-343 Kraków \\ E-mail: leskiew@if-pan.krakow.pl
}

\title{
NEUROSTEROIDY - MODULATORY OŚRODKOWEGO UKŁADU NERWOWEGO
}

\section{NEUROAKTYWNE STEROIDY - GENOMOWY I NIEGENOMOWY MECHANIZM DZIAEANIA}

Przypadkowe odkrycie kilkadziesiąt lat temu właściwości nasennych i przeciwdrgawkowych progesteronu zapoczatkowało badania nad wplywem hormonów steroidowych na aktywność neuronów (SELYE 1942, ATKINSON i współaut. 1965). Steroidy: hormony płciowe, glikokortykosteroidy, mineralokortykosteroidy, łatwo przenikaja do ośrodkowego układu nerwowego (OUN) modulując jego pobudliwość. Regulują one funkcje OUN głównie na drodze złożonego procesu zwiazanego $z$ regulacja transkrypcji genów, przy udziale receptorów cytoplazmatycznych/ jadrowych (ang. genomic action). Niektóre hormony steroidowe, np. 17ß-estradiol, wiażą się $z$ receptorami błonowymi zwiazanymi $z$ białkami G (ang. G Protein-coupled estrogen receptor, GPER), aktywując wewnątrzkomórkowe szlaki sygnałowe (ang. non-genomic action). Steroidy syntetyzowane w mózgu, czyli neurosteroidy, moga również aktywować jonotropowe receptory błonowe (Ryc. 1) (SINGH i współaut. 2013, GASSER i LOWRY 2018). W klasycznej "genomowej” ścieżce, cząsteczki steroidów przyłączaja się do cytoplazmatycznych receptorów steroidowych należących do podrodziny receptorów jadrowych, czyli zależnych od liganda czynników transkrypcyjnych, które po aktywacji wiążą się do odpowiednich sekwencji DNA i bezpośrednio reguluja transkrypcje genów lub oddziałuja $z$ innymi czynnikami transkrypcyjnymi, wpływając na ekspresję genów docelowych. Wpływ steroidów na ekspre- sję genów jest procesem skomplikowanym, wieloetapowym i długotrwałym, co oznacza, że pierwsze zmiany ekspresji genów, będace następstwem działania hormonów steroidowych, zaobserwować można co najmniej po kilku godzinach od ekspozycji. Czasteczka steroidowa po wniknięciu do cytoplazmy przyłącza się do kompleksu receptorowego. Receptor $\mathrm{w}$ formie nieaktywnej jest połaczony $z$ białkami opiekuńczymi Hsp70, Hsp90 i p23 oraz immunofilinami $z$ rodziny białek FK506. Po zwiazaniu steroidowego liganda następuje oddysocjowanie białek opiekuńczych, fosforylacja (aktywacja) receptora, który, jako homodimer, przemieszcza się do jadra. Tam ulega kolejnej dimeryzacji i razem z koregulatorami przyłącza się do odpowiedniego fragmentu DNA, tzw. elementu HRE (ang. hormone-response element). Koregulatory albo promuja transkrypcję (koaktywatory, np. SRC-1; ang. steroid receptor co-activator) albo ja hamuja (korepresory, np. NCoR; ang. nuclear receptor corepressor). Poprzez mechanizm genomowy hormony steroidowe wpływaja m.in. na działanie klasycznych neuroprzekaźników regulując ich syntezę, metabolizm i gęstość ich receptorów. Przykładowo, kortykosteron (glikokortykosteroid występujący u gryzoni) nasila aktywność enzymów syntetyzujących neuroprzekaźniki (noradrenalinę czy serotoninę) $\mathrm{w}$ ośrodkowym układzie nerwowym, $\mathrm{z}$ kolei przedstawiciel estrogenów 17ß-estradiol wpływa na liczbę receptorów dla hormonu oksytocyny, receptorów GABA czy receptorów serotoninowych (BIEGON i MCEwEN 1982, SCHUMACHER i współaut. 1989). Inny sposób 


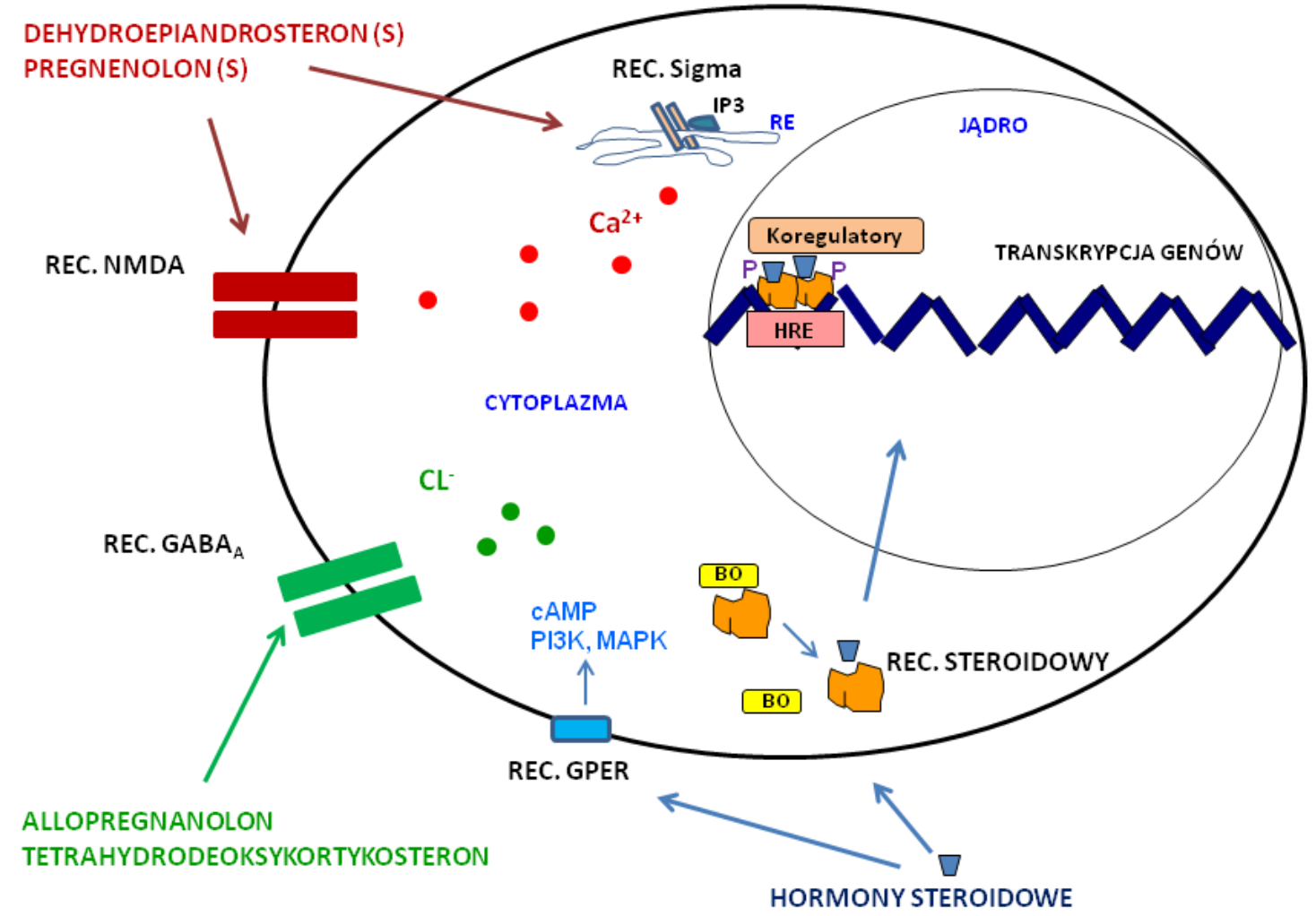

Ryc. 1 Schemat działania steroidów - różne mechanizmy receptorowe.

ER - siateczka śródplazmatyczna; BO - białka opiekuńcze; P - grupy fosforylowe; HRE - sekwencja DNA przyłączajaca kompleks receptorowy; GPER - receptor błonowy dla estradiolu; cAMP - cykliczny adenozyno-3',5'-monofosforan; PI3K - kinaza fosfatydyloinozytolu; MAPK - kinazy aktywowane mitogenami; IP3 - receptor tórjfosforanu inozytolu.

działania estradiolu (ang. rapid signaling) to aktywacja błonowego receptora GPER. Receptor ten występuje w błonie komórkowej i w wewnątrzkomórkowych błonach siateczki śródplazmatycznej (ang. endoplasmic reticulum, ER) i aparatu Golgiego. Jego pobudzenie może modulować wewnatrzkomórkowe stężenie $\mathrm{Ca}^{2+}$, produkcję cAMP oraz wpływać na aktywność enzymów: kinazy PI3K (ang. phosphatidylinositol 3-kinase) czy kinaz aktywowanych mitogenem MAPKs (ang. mitogen-activated protein kinases) (ROQUE i współaut. 2019). W ten sposób hormon ten reguluje uwalnianie neurotrofin i wiele procesów komórkowych takich jak: wzrost komórek, ich przeżycie, migrację czy tworzenie nowych naczyń krwionośnych.

Innym szybkim rodzajem oddziaływania steroid-receptor charakteryzują się neurosteroidy syntetyzowane $\mathrm{w}$ OUN i wywierajace natychmiastowy efekt na aktywność neuronów, a różniące się od klasycznych hormonów steroidowych mechanizmem działania. Neurosteroidy sa i prekursorami i metabolitami hormonów steroidowych, jednak określone cechy w budowie ich cząsteczki umożliwiaja im interakcję $z$ receptorami in- nymi niż steroidowe. Nazwa "neurosteroidy” pojawiła się po raz pierwszy w pracy BAULIEU i ROBEL (1990) i oznaczała steroidy syntetyzowane w mózgu, natomiast PAUL i PURDY (1992) posługiwali się nazwa "neuroaktywne steroidy", która oznaczała steroidy syntetyzowane w gruczołach obwodowych, ale działajace na ośrodkowy układ nerwowy. Obecnie obie nazwy sa używane głównie dla steroidów syntetyzowanych w mózgu i działających za pośrednictwem jonotropowych receptorów błonowych, głównie hamujacych

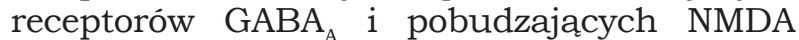
(REDDY 2003, AKK i współaut. 2009). Ze względu na modulacyjny charakter oddziaływania neurosteroidów $z$ receptorami jonotropowymi i bezpośredni wpływ na pobudliwość neuronów, stanowią one ciekawą grupę zwiazków, które mogłyby znaleźć zastosowanie w terapii niektórych zaburzeń OUN.

\section{NEUROSTEROIDY - SYNTEZA I PODZIAE}

„Fabryka” neurosteroidów znajduje się w komórkach glejowych: astrocytach i oligodendrocytach i neuronach (JUNG-TESTAS 


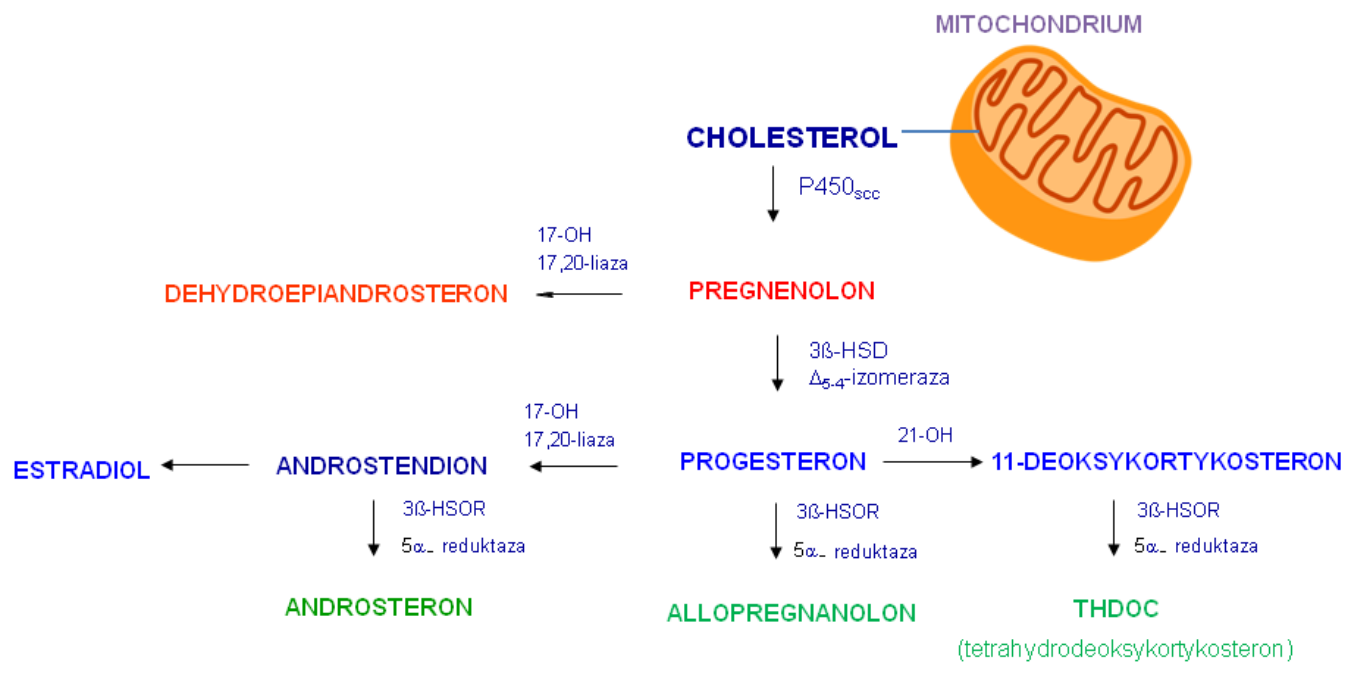

Ryc. 2 Główne szlaki syntezy neurosteroidów.

OH - hydroksylaza; HSD - dehydrogenaza hydroksysteroidowa; HSOR - oksydoreduktaza hydroksysteroidowa; R reduktaza.

i współaut. 1989). Dzięki obecności enzymów w komórkach mózgu, neurosteroidy moga w nich powstawać niezależnie od dostaw $z$ obwodu. Substratem do ich syntezy jest cholesterol lub prekursory hormonów steroidowych pochodzące ze źródeł obwodowych. Prekursory steroidowe latwo i szybko przenikają do mózgu, stanowiąc niewyczerpalne źródło substratów do biosyntezy neurosteroidów. Cały proces produkcyjny rozpoczyna się od przemieszczenia cząsteczki cholesterolu $z$ zewnętrznej do wewnętrznej części błony mitochondrialnej, przy czym uczestniczą w tym wyspecjalizowane białka, które działaja jak „prom” pomiędzy błonami, a sa to: białko StAR (ang. steroidogenic acute regulatory protein), białko TSPO (ang. translocator protein), kanał anionowy zależny od napięcia VDAC (ang. voltage-dependent anion channel) i białko ATAD3A należace do rodziny ATP-az (ang. ATPase family AAA-domain containing protein 3A). Dzięki tym wyspecjalizowanym cząsteczkom, cholesterol dociera do właściwego miejsca $\mathrm{w}$ obrębie mitochondrium, gdzie rozpoczyna się proces syntezy (DIOTEL i współaut. 2018). Po „zakotwiczeniu” cholesterolu w wewnętrznej błonie mitochondrialnej, jego

\section{Neurosteroidy hamujące}

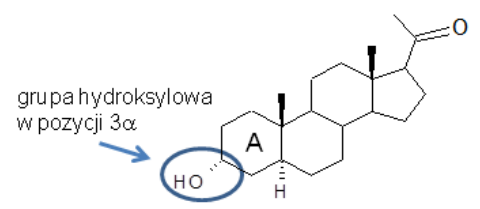

Allopregnanolon

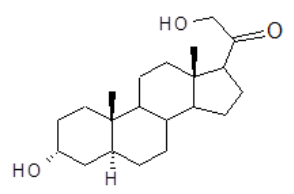

Allotetrahydrodeoksykortykosteron

\section{Neurosteroidy pobudzające}<smiles>O=C1CCC2C1CCC1C3CCC(O)CC3=CCC21</smiles>

Dehydroepiandrosteron - DHEA (S)<smiles>CC(=O)C1CCC2C1CCC1C3CCC(O)CC3=CCC12</smiles>

Pregnenolon - PREG (S)

Ryc. 3 Wzory strukturalne neurosteroidów hamujących i pobudzajacych. 
boczny łańcuch ulega odszczepieniu przy udziale cytochromu P-450scc (ang. side chain cleavage) i powstaje pregnenolon - pierwszy neurosteroid i zarazem główny prekursor hormonów i innych neurosteroidów, po czym w kolejnych etapach odpowiednie enzymy doprowadzaja do powstania szeregu różnych pochodnych steroidowych (STOFFEL-WAGNER 2003). Pod wpływem dehydrogena-

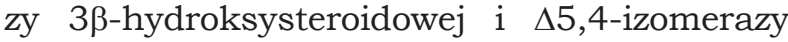
powstaje hormon progesteron, natomiast pod wpływem 17 $\alpha$-hydroksylazy i 17,20-liazy powstaje neurosteroid dehydroepiandrosteron. Nastepnie, przy udziale $5 \alpha$-reduktazy i oksydoreduktazy 3 $\alpha$-hydroksysteroidowej, $z$ progesteronu powstaje allopregnanolon, $z$ 11-deoksykortykosteronu tetrahydrodeoksykortykosteron, $z$ androstendionu $5 \alpha$-androstan-3 $\alpha$-ol-17-on, czyli androsteron, który jest i hormonem i neurosteroidem, natomiast $z$ testosteronu $5 \alpha$-androstan-3 $\alpha, 17 \beta$ diol. (Ryc. 2)

Powstałe w tych przemianach czasteczki steroidowe posiadajace $\mathrm{w}$ swej budowie chemicznej zredukowany pierścień A i grupe hydroksylowa w pozycji $3 \alpha$ - staja się „kluczem do zamka”, czyli hamujacego receptora GABA $_{\mathrm{A}}$ (Ryc. 3). Ze względu na strukturę chemiczna, neurosteroidy można podzielić na: pochodne pregnanu - allopregnanolon (ALLOP), allotetrahydrodeoksykortykosteron (THDOC), pochodne androstanu - androstanediol, androsteron oraz pochodne siarczanowe - siarczan pregnenolonu (PS) i siarczan dehydroepiandrosteronu (DHEAS). Ze względu na rodzaj oddziaływania w mózgu neurosteroidy możemy podzielić na hamujące, czyli takie, które aktywuja receptor GABA - ALLOP, THDOC, oraz pobudzajace, czyli takie, które aktywują receptor NMDA - PS i DHEAS (Ryc. 3). Neurosteroidy pobudzajace, czyli dehydroepiandrosteron i pregnenolon, występują w mózgu w wysokim stężeniu, w postaci wolnej lub jako estry kwasu siarkowego, a ich stężenie w małym stopniu zależy od wydzielania obwodowego.

\section{NEUROSTEROIDY I RECEPTOR GABA}

Receptor $\mathrm{GABA}_{\mathrm{A}}$ jest pentamerycznym kompleksem białkowym, w skład którego wchodzia 4 podjednostki polipeptydowe $(\alpha, \beta$, $\gamma, \delta)$ ułożone w określonych kombinacjach i tworzace ściany kanału chlorkowego. Skład podjednostkowy determinuje stopień i sposób działania związów modulujących przepływ jonów chlorkowych. Postsynaptyczne receptory $\mathrm{GABA}_{\mathrm{A}}$ zbudowane sa $z$ dwóch podjednostek $\alpha$, dwóch $\beta$ i jednej $\gamma$, natomiast receptory zlokalizowane na zewnatrz synapsy maja dwie podjednostki $\alpha$, dwie $\beta$ i jedna $\delta$. Aktywacja receptora $\mathrm{GABA}_{\mathrm{A}}$ prowadzi do napływu jonów chlorkowych do wnętrza komórki, hiperpolaryzacji błony komórkowej i, w konsekwencji, do obniżenia pobudliwości. Wyróżnia się dwa rodzaje hamujacej neurotransmisji GABA-ergicznej: fazowa i toniczną. Hamowanie fazowe odpowiada za szybka transmisję sygnału $z$ jednego neuronu do drugiego (przerywane uwalnianie wysokich stężeń GABA $z$ zakończeń presynaptycznych) i zachodzi za pośrednictwem receptorów zlokalizowanych w obrębie synapsy. Hamowanie toniczne natomiast reguluje pobudliwość sieci neuronalnej poprzez ciagła aktywację receptorów zlokalizowanych na zewnątrz szczeliny synaptycznej przez niskie stężenia GABA. Hamowanie toniczne odgrywa przede wszystkim rolę w kontroli pobudliwości hipokampa. W obrębie kompleksu receptora $\mathrm{GABA}_{\mathrm{A}}$, obok głównego miejsca wiazania neuroprzekaźnika, występuje wiele miejsc regulatorowych, wiażacych m.in. zwiazki uspokajajace/nasenne jak: benzodiazepiny i barbiturany, neurosteroidy, oraz miejsca przyłączania antagonistów (pikrotoksyna, bikukulina - toksyny wywołujące drgawki) (Ryc. 4). Efekt farmakologiczny tych zwiazków uzależniony jest od kompozycji podjednostek receptora. Badania biochemiczne i elektrofizjologiczne dowiodły, że neurosteroidy sa endogennymi modulatorami receptora $\mathrm{GABA}_{\mathrm{A}} \mathrm{i}$ to zarówno pozytywnymi, jak i negatywnymi. Uważa się, że istnieja co najmniej trzy różne miejsca wiążące neurosteroidy na receptorze GABA: miejsce allosterycznej i bezpośredniej aktywacji receptora (allopregnanolon, THDOC) oraz miejsce przyłączania neurosteroidu pobudzajacego (siarczan pregnenolonu) (HosiE i współaut. 2007). Wśród neurosteroidów wykazujących wysokie powinowactwo do receptora i będacych agonistami należa m.in.: allopregnanolon, pregnanolon, THDOC, androsteron oraz syntetyczne neurosteroidy, jak alfaksalon czy ganaksolon. Neurosteroidy, oprócz bezpośredniej aktywacji receptora, mogą również działać pośrednio, poprzez nasilanie lub hamowanie wiazania innych ligandów. W stężeniach nanomolarnych wzmagaja działanie kwasu GABA oraz nasilają wiazanie do receptora $\mathrm{GABA}_{\mathrm{A}}$ muscimolu (alkaloid występujacy w muchomorach, agonista receptora $\mathrm{GABA}_{\mathrm{A}}$ ) i benzodiazepin, natomiast allosterycznie hamuja wiazanie $t-$ -butylobicyklofosforotionianu (TBPS, silny antagonista receptora $\mathrm{GABA}_{\mathrm{A}}$,). W wysokich stężeniach mikromolarnych neurosteroidy bezpośrednio moga otwierać kanał chlorkowy (MAJEwSKA i współaut. 1986). Działanie zwiększające przepływ prądów chlorkowych zachodzi poprzez wzrost częstotliwości i czasu otwarcia kanału. Ułożenie grupy hydroksylowej w pozycji $3 \beta$ zmienia profil działania neurosteroidów $z$ agonistycznego na antagonistyczny, ale takie pochodne działaja tyl- 


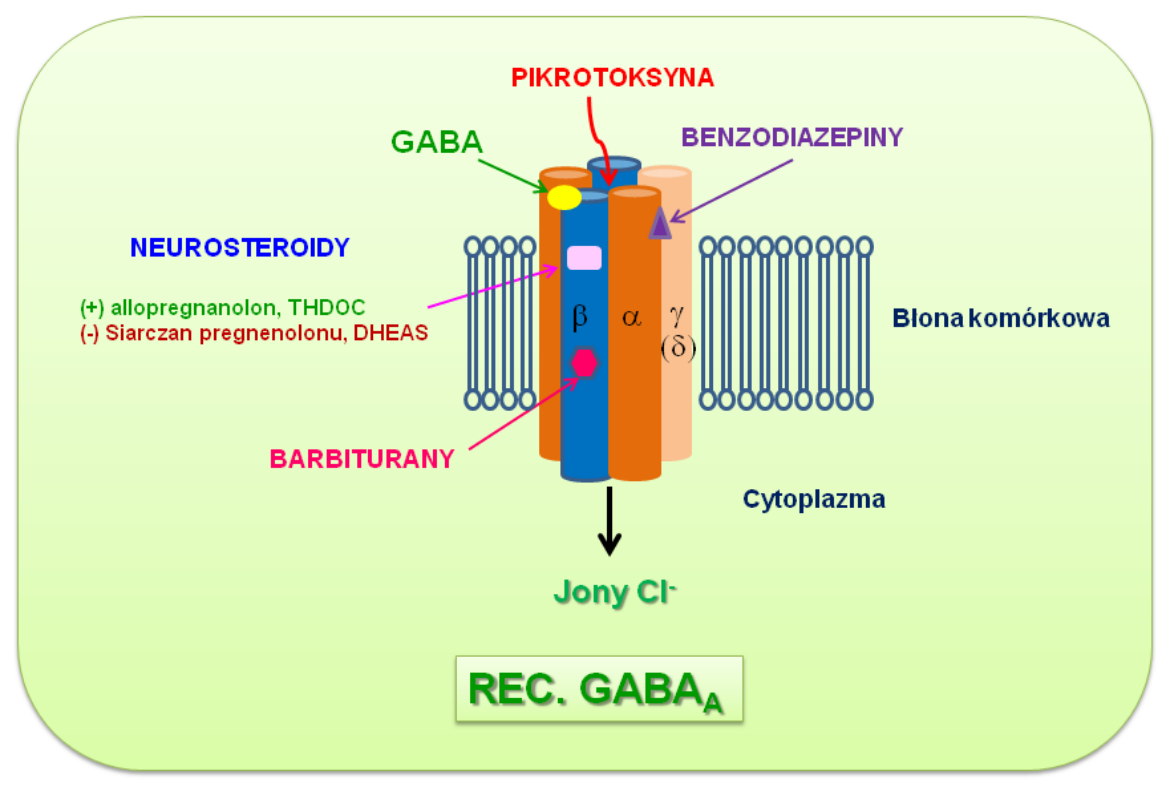

Ryc. 4 Kompleks receptorowy GABA .

$\alpha, \beta, \gamma, \delta$ - podjednostki białkowe otaczające kanał jonowy; GABA-główny agonista, Pikrotoksyna-antagonista, Barbiturany, Benzodiazepiny-agoniści, Neurosteroidy: (+) modulatory pozytywne, (-) modulatory negatywne.

ko w wysokich mikromolarnych stężeniach. Neurosteroidy pobudzające, do których należa pregnenolon i dehydroepiandrosteron (również $\mathrm{w}$ formie siarczanów), są negatywnymi allosterycznymi modulatorami receptora GA$\mathrm{BA}_{\mathrm{A}}$, jednak ich właściwości nie sa identyczne. Uważa się, że siarczan pregnenolonu ma działanie mieszane agonistyczno-antagoni- styczne. W nanomolarnych stężeniach nasila, a w mikromolarnych hamuje wiazanie innych

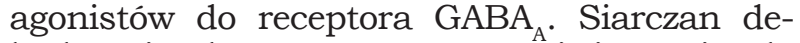
hydroepiandrosteronu, w przeciwieństwie do siarczanu pregnenolonu, nie wpływa na wiazanie innych ligandów do receptora GABA $_{A}$ (MAJEwSKA i współaut. 1990). Przyłączenie grupy siarczanowej do cząsteczki neuroste-

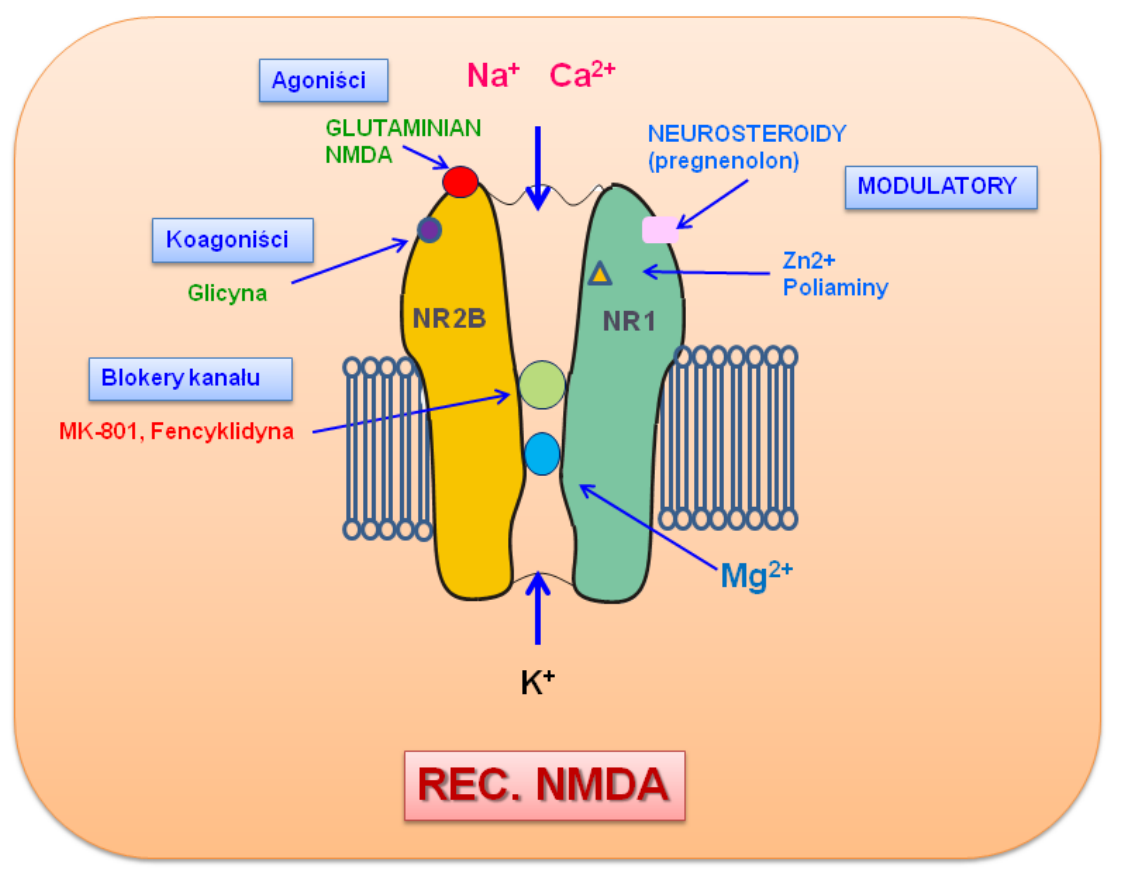

Ryc. 5 Schemat receptora NMDA - rodzaje ligandów; NR1, NR2B - podjednostki tworzące kanał jonowy. 
roidu może odwracać kierunek modulacji receptora $z$ pozytywnego na negatywny, który to proces może być ważnym mechanizmem kontrolującym aktywność endogennych neurosteroidów.

\section{NEUROSTEROIDY I RECEPTOR NMDA}

Obok wpływu na hamujacy system GABA-ergiczny, niektóre neurosteroidy moga również modulować układ pobudzających aminokwasów poprzez wpływ na glutaminianergiczne receptory NMDA (skrót pochodzi od agonisty - kwasu N-metylo-D-asparaginowego). Siarczan pregnenolonu i siarczan dehydroepiandrosteronu sa jego pozytywnymi modulatorami (Wu i współaut. 1990). Receptor ten, podobnie jak receptor $\mathrm{GABA}_{A}$, zbudowany jest $\mathrm{z}$ podjednostek białkowych tworzacych kanał jonowy, przepuszczalny dla jonów $\mathrm{Na}^{+}, \mathrm{Ca}^{2+}, \mathrm{K}^{+}$(Ryc. 5). Ligandy receptora NMDA, w zależności od ułożenia poszczególnych podjednostek, moduluja jego aktywację. Stymulacja miejsca receptorowego przez agonistę powoduje otwarcie kanału wapniowego, napływ zewnattrzkomórkowego wapnia do wnętrza komórki i powstanie prądu jonowego. W obrębie kompleksu receptora NMDA istnieje wiele "stacji dokujacych" dla różnych zwiazków chemicznych: miejsce wiążące neuroprzekaźnik, czyli kwas glutaminowy, miejsca modulacyjne: glicynowe, poliaminowe i miejsce wiążace jony $\mathrm{Zn}^{2+}$. Wewnątrz kanału znajduje się miejsce, do którego wiąża się zwiazki blokujace receptor NMDA, oraz miejsce wiążace jony $\mathrm{Mg}^{2+}$ (DANYSZ 1992) (Ryc. 5). Siarczanowe pochodne neurosteroidów, czyli PS i DHEAS, zalicza się do pozytywnych modulatorów pobudzajacego receptora NMDA, przy czym do aktywacji receptora i powstania prąu jonowego wymagane sa wyższe mikromolarne stężenia neurosteroidów. W licznych badaniach elektrofizjologicznych wykazano, że siarczan pregnenolonu zwiększa częstość i średni czas otwarcia kanału, podnosi indukowane przez NMDA wewnątrzkomórkowe stężenie jonów $\mathrm{Ca}^{2+} \mathrm{w}$ hodowli neuronów hipokampa oraz nasila neurotoksyczne efekty NMDA (IRWIN i współaut. 1992).

\section{INNE MIEJSCA WIAZŻACE DLA NEUROSTEROIDOW}

Neurosteroidy wywieraja wpływ na funkcjonowanie OUN również poprzez inne receptory i kanały jonowe. Obok receptorów GABA $_{\mathrm{A}}$ i NMDA, punktem uchwytu dla siarczanu pregnenolonu i siarczanu dehydroepiandrosteronu sa receptory sigma 1, które występuja w mózgu w dużej gęstości i moduluja różne procesy zależne od jonów $\mathrm{Ca}^{2+}$ : fizjologiczne (procesy uczenia się $\mathrm{i}$ pamięci) i patologiczne (lęk, uzależnienia czy neurodegeneracje). Receptory sigma zlokalizowane sa w błonie siateczki śródplazmatycznej i pełnia funkcję białek opiekuńczych, na poziomie molekularnym moga tworzyć kompleksy $z$ receptorem IP3 (ang. 1,4,5-trisphosphate inositol receptor) czy innymi białkami szoku cieplnego, uczestniczac w kontroli sygnału wapniowego. Pod wpływem niektórych ligandów może zachodzić proces rozłączania białek opiekuńczych, ułatwiając interakcję receptora sigma $z$ innymi receptorami, np. kanałami jonowymi (Tsai i współaut. 2009). Siarczan pregnenolonu i siarczan dehydroepiandrosteronu działaja jako pozytywne modulatory receptorów sigma. Moga one aktywować specyficzne enzymy - kinazy zależne od jonów wapnia: CaMKII (ang. $\mathrm{Ca}^{2+} /$ calmodulin-dependent protein kinase II), PKC (ang. protein kinase C) i ERK (ang. extracellular signal-activated kinase), wywołujac efekty neuroprotekcyjne i poprawiajacc procesy poznawcze i pamięciowe w różnych modelach eksperymentalnych (REBAS i współaut. 2017). Neurosteroidy pobudzające osłabiaja efekty antagonistów receptora NMDA i zapobiegaja deficytom pamięci, pobudzając tworzenie kompleksów receptorów sigma $z$ podjednostkami NR2 receptor NMDA i przemieszczanie się podjednostek do błony komórkowej (MORALES-LÁZARO i współaut. 2019). Modulacyjny, wielokierunkowy wpływ neurosteroidów na jonotropowe receptory w OUN sprawia, że uczestnicza one $\mathrm{w}$ regulacji równowagi pomiędzy systemami hamujących i pobudzajacych aminokwasów w ośrodkowym układzie nerwowym, a więc w mechanizmach stanowiących podstawę procesów m.in.: uczenia się i pamięci, stresu, zaburzeń lękowych, zaburzeń depresyjnych czy stanów drgawkowych.

Innym ciekawym punktem uchwytu dla neurosteroidów jest białko zwiazane $z$ mikrotubulami (ang. microtubule associated protein type-2, MAP-2). Jest ono specyficznym, wewnatrzkomórkowym neuronalnym receptorem dla pregnenolonu. Pregnenolon, wiażąc się $\mathrm{z}$ tym białkiem, staje się modulatorem neuronalnego systemu mikrotubularnego, wpływając na stabilizację cytoszkieletu i wzrost neurytów (BAULIEU 2018). Neurosteroidy działaja więc wielotorowo i moga uczestniczyć w różnych procesach fizjologicznych i patofizjologicznych.

\section{NEUROSTEROIDY - EFEKTY W ZABURZENIACH OŚRODKOWEGO UKŁADU NERWOWEGO}

Skutkiem współdziałania neurosteroidów z hamującymi i pobudzającymi receptorami jonotropowymi jest bezpośredni wpływ na neuroprzekaźnictwo sygnałów w sieciach 
neuronalnych. Działanie neurosteroidów, pochodnych 3 $\alpha$-pregnanu, w ośrodkowym układzie nerwowym zwiazane jest głównie $z$ ich agonistycznym wpływem na hamujacy receptor $\mathrm{GABA}_{\mathrm{A}}$. W zwiąku $z$ tym, allopregnanolon pobudzając ten receptor może uspokoić, uśpić i uciszyć nadmiernie pobudzone neurony (REDDY 2003). Liczne badania na modelach zwierzęcych potwierdziły korzystna rolę neurosteroidów w zaburzeniach lękowych, stresie, depresji i stanach drgawkowych (Ryc. 6). Działanie przeciwlękowe hamujacych neurosteroidów jest blokowane przez antagonistów receptora $\mathrm{GABA}_{\mathrm{A}}$, co dowodzi udziału transmisji GABA-ergicznej w procesach lękowych. Podczas stosowania leków przeciwlękowych $z$ grupy specyficznych inhibitorów wychwytu zwrotnego serotoniny (ang. selective serotonin reuptake inhibitor, SSRI), tj. fluoksetyna czy fluwoksamina, zaobserwowano znaczacy wzrost stężenia allopregnanolonu w mózgu. Okazało się, że oprócz działania zwiększającego stężenie serotoniny, leki $z$ grupy SSRI zwiększaja syntezę hamujacych neurosteroidów poprzez bezpośredni wpływ na aktywność enzymów w procesie steroidogenezy. Ten efekt leków może być jednym $z$ mechanizmów działania przeciwlękowego. W badaniach klinicznych obserwowano obniżone poziomy allopregnanolonu we krwi i płynie mózgowo-rdzeniowym u pacjentów $z$ depresja, który wracał do normy w trakcie terapii lekami przeciwdepresyjnymi. Szczególna jednostka chorobową, w której obserwuje się skuteczne działanie allopregnanolonu, jest depresja poporodowa. Nagły spadek stężenia progesteronu po porodzie oraz zaburzenie osi podwzgórze-przysadka mózgowa-nadnercza powoduje zaburzenie równowagi między procesami pobudzenia i hamowania, co może prowadzić do nadpobudliwości, czyli zachowań lęko- wych i depresyjnych. Podczas gdy u wielu kobiet w okresie okołoporodowym obserwuje się niewielkie i przejściowe zmiany nastroju, to jednak depresja poporodowa jest poważnym, długo trwajaccym, niekorzystnym stanem chorobowym. Allopregnanolon, który wzmaga toniczne hamowanie poprzez receptor $\mathrm{GABA}_{\mathrm{A}}$, odwraca te zmiany, co wykazano $\mathrm{w}$ badaniach przedklinicznych i klinicznych. Pozytywne, potwierdzone korzystne efekty allopregnanolonu stały się podstawa do dopuszczenia go, pod nowa nazwa breksanolon (zbuforowany izotoniczny roztwór allopregnanolonu), w 2019 r. do stosowania u kobiet cierpiacych na depresję poporodową. Dożylny wlew breksanolonu powoduje szybka i trwała poprawe nastroju, co potwierdza hipotezę, że bezpośrednie zwiększenie stężenia neurosteroidu jest wysoce skuteczne w terapii tego rodzaju depresji (SCARFF 2019). Innym obiecujacym syntetycznym neurosteroidem pochodnym allopregnanolonu, będącym w zaawansowanej fazie badań klinicznych, jest zuranolon (SGE-217), który, co jest dodatkowym atutem, jest aktywny po podaniu doustnym, i w badaniach klinicznych wykazuje wysoka skuteczność w leczeniu zaburzeń depresyjnych u kobiet i mężczyzn (ZORUMSKI i współaut. 2019). Wprowadzanie neurosteroidow $z$ grupy pochodnych pregnanu do terapii zaburzeń depresyjnych u ludzi potwierdza ich skuteczność oraz dobry profil farmakologiczny. $Z$ drugiej strony, przedstawiciel neurosteroidów pobudzajacych, dehydroepiandrosteron, od kilkudziesiecciu lat jest dostępny na rynku jako suplement diety nazywany "hormonem lub eliksirem młodości”, który ma poprawiać pamięć, opóźniać efekty starzenia i odnawiać układ immunologiczny, jednak w badaniach klinicznych nie pojawiła się jednoznaczna odpowiedź czy rzeczywiście jest on tak skuteczny. Jednak w podstawo-

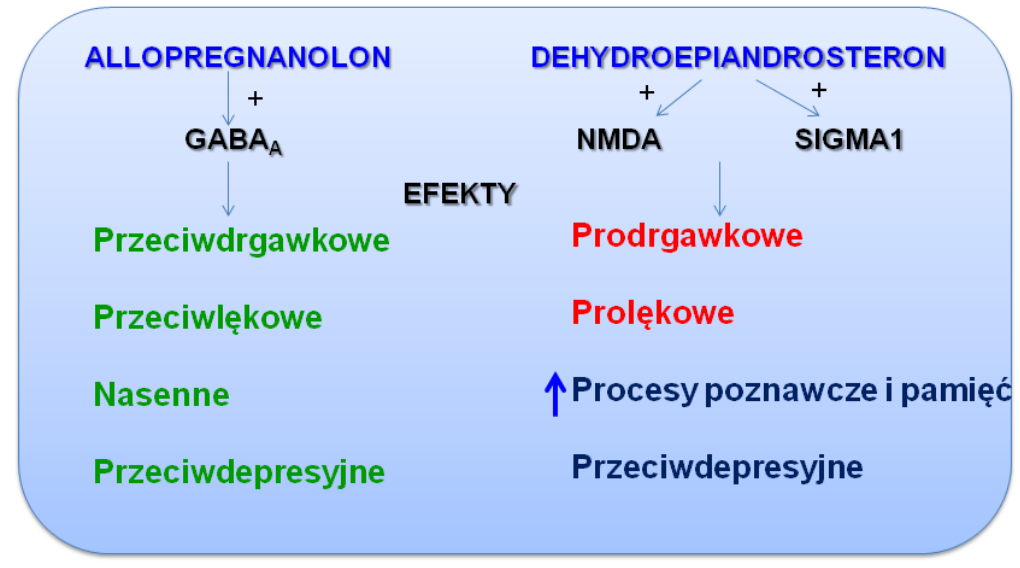

Ryc. 6 Efekty działania neurosteroidów hamujących i pobudzających w ośrodkowym układzie nerwowym. 
wych badaniach eksperymentalnych wykazano jego istotna rolę w procesach uczenia się i pamięci, procesach neuroprotekcyjnych, procesie neurogenezy oraz zaburzeniach depresyjnych. W modelach uczenia się i pamięci neurosteroidy pobudzające okazuja się być pozytywnymi modulatorami, wyrównujacymi deficyty pamięci wywoływane antagonistami receptora NMDA, agonistami receptora muskarynowych czy etanolem, również działanie przeciwlękowe i przeciwdepresyjne wykazano w niektórych modelach behawioralnych, a ich uspokajajace efekty tłumaczy się stymulujacym wpływem na receptory sigma1 (MAURICE i współaut. 1999, DHIR i KULKARNI 2008). Dysfunkcje poznawcze zwiazane sa ze spadkiem stężenia dehydroepiandrosteronu $\mathrm{w}$ procesie starzenia i chorobie Alzheimera. Przywrócenie prawidłowego poziomu pobudzajacych neurosteroidów daje korzystne rezultaty w postaci wyrównania deficytów pamięciowych i poprawy funkcji poznawczych (REDDY 2003, KLINGE i współaut. 2018). Niskie poziomy DHEA obserwuje się również u pacjentów $z$ depresja, a wyrównanie jego poziomu istotnie poprawia nastrój. Dobre efekty obserwuje sie w skojarzonym podawaniu klasycznych leków przeciwdepresyjnych $z$ DHEA, jednak mechanizm tego oddziaływania nie jest do końca poznany. Przedmiotem badań eksperymentalnych jest również związek MAP4343 (3ß-metoksypregnenolon), który jest syntetyczna pochodna pregnenolonu bez działania hormonalnego. Podobnie jak pregnenolon, MAP4343 wią̇e się do białka MAP-2, modyfikujac funkcje systemu mikrotubularnego. W modelach zwierzęcych jest to zwiazek bardzo aktywny, działa przeciwlękowo i przeciwdepresyjnie, jednak pozostaje do wyjaśnienia, czy jego wpływ na zmiany izoform białka tubuliny ma związek $z$ procesami lęku i depresji (PARÉsYs i współaut. 2016).

Neurosteroidy (pochodne 3 $\alpha$-pregnanu), agoniści receptora $\mathrm{GABA}_{A}$, okazały się niezwykle skutecznymi zwiąkami przeciwdrgawkowymi, co zostało wykazane $\mathrm{w}$ wielu modelach eksperymentalnych $\mathrm{z}$ użyciem substancji wywołujacych drgawki o różnym mechanizmie działania. Przede wszystkim hamujace neurosteroidy sa skuteczne w drgawkach wywoływanych antagonistami receptora $\mathrm{GABA}_{\mathrm{A}}$, czyli pikrotoksyna, bikukulina czy pentylenetetrazolem. Posiadaja jednak szersze spektrum działania, wykazujac efekty przeciwdrgawkowe $\mathrm{w}$ modelach drgawek wywoływanych kwasem kainowym, NMDA, pilokarpina, nikotyna, kokaina i penicyliną (LEŚKIEWICZ i współaut. 1997, BUDZISZEWSKA i współaut. 1998). Zmiany w poziomach hormonów $\mathrm{u}$ kobiet $\mathrm{z}$ napadami padaczkowymi maja wpływ na pobudliwość drgawkowa, a przy obniżonym poziomie progesteronu zwiększa się prawdopodobieństwo napadu drgawkowego (RoŚCISZEWSKA i współaut. 1986). Istnieje więc odwrotna korelacja pomiędzy stężeniem progesteronu i jego pochodnych a podatnościa na wystapienie drgawek. Skuteczne przeciwdrgawkowe efekty hamujących neurosteroidów skłoniły badaczy do poszukiwania syntetycznych pochodnych allopregnanolonu, o lepszej biodostępności, trwałości i bez aktywnych metabolitów. W 1989 r. PETERSON wykazał przeciwdrgawkowe efekty preparatu „Saffan”, środka znieczulającego, będacego mieszanina syntetycznych neurosteroidów: alfaksalonu $i$ alfadolonu. Innym skutecznym zwiazkiem przeciwdrgawkowym okazał się syntetyczny analog allopregnanolonu, ganaksolon (ang. Ganaxolone 3 $\beta$-methyl-3a-ol-5a-pregnan-20one), różniący się od allopregnanolonu dodatkowa grupa metylowa $\mathrm{w}$ pozycji $3 \beta$. Taki układ struktury chemicznej zapewnia stabilność związku, zapobiega przekształcaniu do hormonalnych prekursorów i zwiększa biodostępność po podaniu doustnym. Ponadto, w przeciwieństwie do benzodiazepin, wielokrotne podania ganaksolonu nie doprowadzaja do rozwoju tolerancji oraz istnieje większa różnica pomiędzy dawką przeciwdrgawkowa a nasenna (GÁsIOR i współaut. 2000). W związku $z$ wysoka przeciwdrgawkową skutecznościa ganaksolonu $\mathrm{w}$ badaniach eksperymentalnych, jest on obecnie w fazie badań klinicznych pod katem skutecznego działania przeciwpadaczkowego w jednostkach chorobowych takich jak: padaczka oporna na leczenie, padaczka o podłożu genetycznym u dzieci i stan padaczkowy (Younus i REDDY 2018, ChuANG i RedDY 2020). Obecnie prowadzone są również badania kliniczne dotyczace zastosowania alfaksalonu (3-hydroksy$5 \alpha$-pregnan-11,20-dion) jako środka znieczulającego u ludzi. Preparat zawierajacy alfaksalon - Alfaxan, jest aktualnie stosowany jako środek znieczulajacy $\mathrm{w}$ weterynarii, natomiast Phaxan (roztwór alfaksalonu z cyklodekstryna do stosowania dożylnego) jest w trakcie badań klinicznych u ludzi. Wyniki licznych badań wskazuja, że zarówno endogenne, jak i syntetyczne pochodne neurosteroidów hamujacych, cechujace się lepsza biodostępnościa i brakiem działania hormonalnego, moga znaleźć zastosowanie w klinice potwierdzając ich skuteczność w procesach zwiazanych $z$ nasilaniem hamujacej transmisji GABA-ergicznej.

\section{PODSUMOWANIE}

Ośrodkowe efekty neurosteroidów były i sa nadal przedmiotem badań eksperymentalnych w modelach chorób takich jak: depre- 
sja, schizofrenia, zaburzenia lękowe, drgawkowe czy zaburzenia pamięci. Neurosteroidy hamujace i pobudzajace, modulując funkcje mózgowych receptorów jonotropowych, moga „uspokajać" nadmiernie pobudliwe neurony działając nasennie, przeciwlękowo, przeciwdepresyjnie i przeciwdrgawkowo, jak również wyrównywać deficyty poznawcze i pamięciowe, poprawiać nastrój, przywracajac tym samym równowage $w$ niektórych zaburzeniach OUN. Z uwagi na fakt, że terapia zaburzeń psychicznych wiąże się $z$ koniecznością długotrwałego stosowania leków, często ze słabym działaniem i niepożądanymi skutkami ubocznymi, wprowadzanie do badań klinicznych endogennych i syntetycznych neurosteroidów o bezpiecznym profilu farmakologicznym wydaje się bardzo obiecujace.

$$
\text { Streszczenie }
$$

Neurosteroidy sa ciekawa grupa związków steroidowych, które moga być syntetyzowane w komórkach ośrodkowego układu nerwowego i modulować aktywność jonotropowych receptorów błonowych. W działaniu steroidów można wyróżnić trzy ścieżki receptorowe. Pierwsza klasyczna, to aktywacja wewnatrzkomórkowych receptorów steroidowych i regulacja transkrypcji genów, druga, nazywana niegenomowa, wiąże się $z$ pobudzeniem receptorów błonowych i aktywacja szlaków przekazu sygnału, i trzeci typ oddziaływania, to interakcja $z$ receptorami jonotropowymi: receptorem kwasu $\gamma$-aminomasłowego $\left(\mathrm{GABA}_{\mathrm{A}}\right)$, receptorem N-metylo-D-asparaginowym (NMDA) i receptorami sigma. Neurosteroidy, modulujacc działanie tych receptorów, moga zmieniać pobudliwość neuronów i dzięki temu uczestniczyć w procesach związanych $z$ neuroprzekaźnictwem hamującym i pobudzającym, działając m.in. uspokajająco, nasennie, przeciwdrgawkowo czy wpływajac na procesy poznawcze. Skuteczność endogennych i syntetycznych neurosteroidów w modelach eksperymentalnych jest potwierdzana w próbach klinicznych zaburzeń depresyjnych, padaczkowych oraz jako środki znieczulające.

\section{LITERATURA}

AkK G., Covey D. F., Evers A. S., Steinbach J. H., ZORUMSKI C. F., MENNERICK S., 2009. The influence of the membrane on neurosteroid actions at $G A B A(A)$ receptors. Psychoneuroendocrinology 34 (Suppl 1), S59-66.

AtKinson R. M., DAVIS B., PRATT M. A., Sharpe H. M., TOMICH E. G., 1965. Action of some steroids on the centtral nervous system of the mouse. II. Pharmacology. J. Med. Chem. 8, 426-432.

BAULIEU E. E., 2018. Steroids and brain, a rising bio-medical domain: a perspective. Front. Endocrinol. 15, 316.

BAUlieu E. E., RoBel P., 1990. Neurosteroids: a new brain function? J. Steroid Biochem. Mol. Biol. 37, 395-403.

BIEGON A., MCEWEN B. S., 1982. Modulation by estradiol of serotonin receptors in brain. J. Neurosci. 2, 199-205.

BudZisZeWSKa B., SiWANOWICZ J., LEŚKIEWICZ M., JAWORSKA-FEIL L., LASOŃ W., 1998. Protective effects of neurosteroids against NMDA-induced seizures and lethality in mice. Eur. Neuropsychopharmacol. 8, 7-12.
CHUANG S. H., REDDY D. S., 2020. Isobolographic analysis of antiseizure activity of the GABA type $A$ receptor-modulating synthetic neurosteroids brexanolone and ganaxolone with tiagabine and midazolam. J. Pharmacol. Exp. Therapeut. 372, 285-298.

DANYSZ W., 1992. Kompleks receptora NMDA. Pobudzajace aminokwasy, IX Szkoła Zimowa Instytutu Farmakologii PAN, Mogilany, Ed. Pilc A., $15-25$.

DHIR A., KULKARNI S., 2008. Involvement of sigma (sigma1) receptors in modulating the anti-depressant effect of neurosteroids (dehydroepiandrosterone or pregnenolone) in mouse tail-suspension test. J. Psychopharmacol. 22, 691-696.

Diotel N., Charlier T. D., LEFEBVRE D'HELlenCourt C., Couret D., Trudeau V. L., Nicolau J. C., Meilhac O., KaH O., Pellegrini E., 2018. Steroid transport, local synthesis, and signaling within the brain: roles in neurogenesis, neuroprotection, and sexual behaviors. Front. Neurosci. 20, 84.

Gäsior M., Ungard J. T., BeEkMan M., CARTER R. B., WITKIN J. M., 2000. Acute and chronic effects of the synthetic neuroactive steroid, ganaxolone, against the convulsive and lethal effects of pentylenetetrazol in seizure-kindled mice: comparison with diazepam and valproate. Neuropharmacology 39, 1184-1196.

GASSER P. J., LOWRY C. A., 2018. Organic cation transporter 3: A cellular mechanism underlying rapid, non-genomic glucocorticoid regulation of monoaminergic neurotransmission, physiology, and behavior. Horm. Behav. 104, 173-182.

Hosie A. M., Wilkins M .E., SMART T. G., 2007. Neurosteroid binding sites on GABA(A) receptors. Pharmacol. Therapeut. 116, 7-19.

IRWIN R. P., MARAGAKIS N. J., ROGAWSKI M. A., PURDY R. H., FARB D. H., PAUL S. M., 1992. Pregnenolone sulfate augments NMDA receptor mediated increases in intracellular $\mathrm{Ca} 2+$ in cultured rat hippocampal neurons. Neurosci. Lett. $141,30-34$.

Jung-Testas I., Hu Z. Y., Baulieu E. E., Robel P., 1989. Neurosteroids: biosynthesis of pregnenolone and progesterone in primary cultures of rat glial cells. Endocrinology 125, 20832091.

Klinge C. M., Clark B. J., Prough R. A. 2018. Dehydroepiandrosterone research: past, current, and future. Vitam. Horm. 108, 1-28.

LEŚKIEWICZ M., BUDZISZEWSKA B., JAWORSKA-FEIL L., LASOŃ W., 1997. Effects of neurosteroids on kainate-induced seizures, neurotoxicity and lethality in mice. Pol. J. Pharmacol. 49, 411417.

MAJEWSKa M. D., HARRISON N. L., SchWARTZ R. D., BARKER J. L., PAUL S. M., 1986. Steroid hormone metabolites are barbiturate-like modulators of the GABA receptor. Science 232, 1004-1007.

MAJEWSKA M. D., DEMIRGÖREN S., LONDON E. D., 1990. Binding of pregnenolone sulfate to rat brain membranes suggests multiple sites of steroid action at the GABAA receptor. Eur. J. Pharmacol. 189, 307-315.

Maurice T., Phan V. L., URANi A., Kamei H., NODA Y., NABESHIMA T., 1999.' Neuroactive neurosteroids as endogenous effectors for the sigma1 (sigma1) receptor: pharmacological evidence and therapeutic opportunities. Jap. J. Pharmacol. 81, 125-155.

MoRALES-LÁZARO S. L., GONZÁlEZ-RAMíREZ R., Rosenbaum T., 2019. Molecular interplay be- 
tween the sigma-1 receptor, steroids, and ion channels. Front. Pharmacol. 10, 1-12.

PAUL S. M., PURDY R. H., 1992. Neuroactive steroids. FASEB J. 6, 2311-2322.

Peterson S. L., 1989. Anticonvulsant profile of anaesthetic steroids. Neuropharmacology 28 , 877-879.

Parésys L., Hoffmann K., Froger N., Bianchi M., Villey I., BAUlieU E. E., FUCHS E., 2016. Ef fects of the synthetic neurosteroid: $3 \beta$-methoxy pregnenolone (MAP4343) on behavioral and physiological alterations provoked by chronic psychosocial stress in tree shrews. Int. J. Neuropsychopharmacol. 20, doi: 10.1093/ ijnp/pyv119.

REBAS E., RADZIK T., BOCZEK T., ZYLINSKA L., 2017. Calcium-engaged mechanisms of nongenomic action of neurosteroids. Curr. Neuropharmacol. 15, 1174-1191.

REDDY D. S., 2003. Pharmacology of endogenous neuroactive steroids. Crit. Rev. Neurobiol. 15, 197-234.

Rooue C., MEndes-Oliveira J., DuARTE-CHENDO C., BALTAZAR G., 2019. The role of $G$ protein-coupled estrogen receptor 1 on neurological disorders. Front. Neuroendocrinol. 55, 100786

RoŚCISZEWSKA D., BUNTNER B., GUZ I., ZAWISZA L., 1986. Ovarian hormones, anticonvulsant drugs, and seizures during the menstrual cycle in women with epilepsy. J. Neurol. Neurosurg. Psychiat. 49, 47-51.
SCARFF J. R., 2019. Use of brexanolone for post partum depression. Innovat. Clin. Neurosci. $16,32-35$.

SCHUMACHER M., COIRINI H., FrankfurT M., MCEWEN B. S., 1989. Localized actions of progesterone in hypothalamus involve oxytocin. Proc. Natl. Acad. Sci. USA 86, 6798-6801.

SelYE H., 1942. The antagonism between anaesthetic steroid hormones and pentamethy lenetetrazol (metrazol). J. Lab. Clin. Med. 27, 1051-1053.

SingH M., Su C., NG S., 2013. Non-genomic mechanisms of progesterone action in the brain. Front. Neurosci. 7, 159, 1-7.

STOFFEL-WAGNER B., 2003. Neurosteroid biosynthesis in the human brain and its clinical implications. Ann. N.Y. Acad. Sci. 1007, 64-78.

TSAI S.-Y., HAYASHI T., MORI T., SU T.-P., 2009. Sigma-1 receptor chaperones and diseases. Central Nervous Syst. Agents Med. Chem. 9, 184-189. WU F. S., GIBBS T. T., FARB D. H., 1991. Pregnenolone sulfate: a positive al losteric modulator at the N-methyl-D-aspartate receptor. Mol. Pharmacol. 40, 333-336.

YounUS I., REDDY D. S., 2018. A resurging boom in new drugs for epilepsy and brain disorders. Expert Rev. Clin. Pharmacol. 11, 27-45.

ZORUMSKI C. F., PAUL S. M., COVEY D. F, MENNERICK S., 2019. Neurosteroids as novel antidepressants and anxiolytics: GABA-A receptors and beyond. Neurobiol. Stress 27, 100196.

KOSMOS Vol. 69, 3, 431-440, 2020

MONIKA LEŚKIEWICZ

Department of Experimental Neuroendocrinology, Maj Institute of Pharmacology PAS, 12 Smętna St., 31-343 Krakow, E-mail: leskiew@if-pan.krakow.pl

NEUROSTEROIDS - MODULATORS OF THE CENTRAL NERVOUS SYSTEM

Summary

Neurosteroids are an interesting group of steroid compounds that can be synthesized in the cells of the central nervous system and modulate the activity of ionotropic membrane receptors. There are three receptor pathways in the action of steroids. The first classic is the activation of intracellular steroid receptors and the regulation of gene transcription, the second, called non-genomic, is associated with the stimulation of membrane receptors and activation of signal transmission pathways, and the third type of interaction is related to the effects on ionotropic receptors: the $\gamma$-aminobutyric acid receptor $\left(\mathrm{GABA}_{\mathrm{A}}\right)$, N-methyl-D-aspartate (NMDA) receptor and sigma receptors. By modulating the action of these receptors, neurosteroids can change the excitability of neurons and thus participate in the processes related to inhibitory and excitatory neurotransmission, acting e.g. sedative, hypnotic, anticonvulsant or influencing cognitive processes. The effectiveness of endogenous and synthetic neurosteroids in experimental models is confirmed in clinical trials of depressive disorders, epilepsy and as anesthetic agents. 